\title{
'I AM WRITING THIS WITH MY OWN HAND...': WRITING IN New Testament times
}

Author:

Pieter J.J. Botha ${ }^{1}$

\section{Affiliation:}

${ }^{1}$ Department of New

Testament and Early

Christian Studies,

University of South Africa,

South Africa

\section{Correspondence to:}

Pieter Botha

e-mail:

bothapjj@unisa.ac.za

Postal address:

Department of New

Testament and Early

Christian Studies,

UNISA, PO Box 392,

Pretoria, Gauteng,

0003, South Africa

\section{Keywords:}

writing; New Testament;

literacy; orality; authorship

\section{Dates:}

Received: 03 Aug. 2009

Accepted: 30 Sept. 2009

Published: 16 Dec. 2009

How to cite this article: Botha, P.J.J., 2009, “"I am writing this with my own hand...": Writing in New Testament times', Verbum et Ecclesia 30(2), Art. \#209, 11 pages. DOI: $10.4102 /$ ve.v30i2.209

\section{This article is available} at: http://www.ve.org.za
(C) 2009. The Authors. Licensee: OpenJournals Publishing. This work is licensed under the Creative Commons Attribution License.

\section{ABSTRACT}

When the New Testament and early Christian writings are considered as situated, culturally mediated and historically functional events, the pitfall of a binary contrast between literacy and orality should be avoided. Focus should be on the physical and experiential aspects of ancient writing. Discussions of posture, education, cost and the amount of time involved in physical writing in Greco-Roman times are concluded by an analysis of the disposition of subservience that surrounded writing.

\section{INTRODUCTION}

It has become quite fashionable to emphasise the pitfalls of anachronism when attempting historical interpretation of texts, and rightly so; proper contextualisation is of considerable importance to responsible analysis and understanding.

A seemingly innocuous question concerns the physical and material aspects of writing in antiquity. Yet, the historical appropriateness of some proposals regarding how the oral tradition about Jesus became written texts, for instance, requires consideration of the concrete aspects of writing in the Roman Mediterranean world. What we perceive a text to be, and how we should go about understanding it, are influenced by what we think about how the text came into being.

In a nutshell, the following article proposes that we will gain a better historical grasp on the early Christian texts when we study the realia of writing. In this study I focus on some of the physical constraints and characteristics of writing in antiquity.

\section{WRITING UPON ONE'S KNEES}

In her discussion of the 'illiterate mode' of medieval written communication Denise Troll notes that the

material and tools were so problematic that they affected the process of book production and the appearance of the books produced - which in turn affected the cost, availability, and the quality of books, and the medieval experience of reading and writing.

(Troll 1990:99)

The physical position adopted in writing is part of the experience of writing, and, consequently, is of importance to the understanding of some of the social, epistemological and psychological ramifications of writing. Interestingly enough, much about the posture of writing in antiquity is often assumed. For instance, recall Mack's description of the creation of the Gospel of Mark: 'It was composed at a desk in a scholar's study lined with texts and open to discourse with other intellectuals' (Mack 1988:322-323).

It is well known that the ancient Egyptian scribe did not use a table when writing.

When writing on a roll, the Egyptian always sat and this is the position displayed by statues of scribes....

Egyptians sat either with the hind part of the body on the ground with the legs crossed in front or with the body resting on the crossed legs.... In a squatting position the loin cloth of the scribe is tightly stretched so as to provide a firm support for the papyrus... He never uses a table of any kind.

(Černý 1952:13-14)

Like the Egyptians, the Greeks and Romans did not use tables or writing desks, but it seems that they sometimes sat on a seat of some kind when writing. The papyrus roll was spread upon the lap or placed upon one knee or thigh (Parássoglou 1985). A small tablet might have been used for support. A sharpened reed pen (rather than the brush of the classic Egyptian scribes) was used in Greco-Roman writing.

'Writing on one's knees' is quite unlike how a modern scholar works. In antiquity scribes were, typically, not accustomed to writing on tables or desks, as is shown by a wide range of artistic, archaeological, and literary evidence (Parássoglou 1979; Turner \& Parsons 1987:5-6). When a scribe was making relatively brief notes on a wax tablet or on a sheet of papyrus or parchment, he would usually stand and write while holding the writing material in his left hand. In the case of a more extensive task, such as the copying of a lengthy manuscript, a scribe would sit, occasionally on the ground but sometimes on a stool or bench, supporting the scroll or codex on his knees (Metzger 1968:123). Scribes wrote their scrolls or sheets by holding, shifting and balancing their writing materials on their thighs (Metzger 1968:125-126).

An illustration of this is the colophon (scribe's mark, signature or note) at the close of a papyrus scroll containing portions of the third and fourth books of the Iliad (third century), which mentions the cooperation of the stylus, the right hand and the knee in writing: kava mo m megray e dexia;ceir kai; gonu. ${ }^{1}$

1.P.Lond.Lit. 11. See Turner \& Parsons 1987:5 n.13; see also P.Oxy. 2079.21-22. 
Given that such a writing position - often without either back support or crucial forearm support ${ }^{2}$ - is not only uncomfortable, but also physically taxing, the ongoing delegation of writing to servants, slaves and hired craftspersons is particularly noteworthy. Consider, also, the demand of availability: the scribe was required to provide his writing skills in basically any conceivable situation, from the bathroom to the bedroom, from the banquet to the street corner, and often while travelling. Adding to the physical stress was the need to refresh the ink on the reed pen. The ink pot was either placed on the ground, or, as is illustrated in a 3rd-century relief, held by a slave ( $c f$. Parássoglou 1979:10, plate 2).

Such physical constraints affected the appearance of ancient writing. The width of columns (on a scroll) averages about six to nine centimetres, which is the width of an average thigh. In some papyrus writings the successive columns are not exactly vertical; sometimes they incline to one side or the other, and the writing may have a tendency to be larger at the bottom than at the top of the column (Turner \& Parsons 1987:5; cf. Johnson 2004:92, 100).

Only by the eighth century did artistic representations of persons writing on desks or tables begin to appear. By 'the end of the ninth century and throughout the tenth and eleventh centuries, examples of persons writing on desks, tables and stands multiply noticeably' (Metzger 1968:130)

Clearly, there was no desire, want, or perceived need for desks for writing (and reading) in antiquity. The following reasons are conventionally suggested for persisting with the ancient custom of holding on one's lap the scroll or loose pages on which one was writing:

- Writing in antiquity was largely done by slaves. The adoption of writing desks in early medieval times is quite possibly connected with the circumstance that

ancient society, being little concerned with the comfort or efficiency of slaves, provided no artificial support for the professional scribe who was a slave; whereas the medieval scribe, usually a monk, was more likely to improve his means of writing.

(Metzger 1968:132, quoting Meyer)

- The use of the codex became widespread only in late antiquity. Writing a codex makes different demands than writing a scroll. The development of the medieval desk probably served to solve some of the difficulties concerned (Small 1997:155). The growing popularity of large deluxe codices must also have contributed to changes in the customs of scribes (Metzger 1968:133).

The posture of the ancient scribe at work was closely linked with the methods of instruction and the realities of ancient schooling.

At every level, teaching was geared to fit the condition of the ancient classroom, which, if it was provided with seats at all, contained only benches. Most of the time, ancient students had only their knees on which to rest a text...

(Cribiore 2001:131)

Above all, such a posture reflects an attitude: writing was labour. Literariness, high education, though inextricably connected to, nevertheless differed from, the practice of writing. In antiquity a distinction between reading and writing was maintained in ways that seem strange (and problematic) to present perceptions of literacy. Writing and reading were not perceived as different parts of an undifferentiated process, despite their obvious overlap.

\section{'FOR HE WRITES SLOWLY ..'}

The 1st-century Mediterranean world was not an 'illiterate'

2.Of course, ergonomic and physiotherapeutic studies of ancient scribes do not (ho not exist. However investigation of contemporary problems is faily easy. For example, such research hows how forearm support reduces the incidence of musculoskeletal discomfor and disorders: Cook, Burgess-Limerick \& Papalia (2004); Marcus et al. (2002); O'Sullivan et al. (2006); and Rempel et al. (2006). world - but the real issue lies in the meaning of terms such as 'literate' and 'illiterate'. During the Roman Period people of various backgrounds participated in elementary schooling, with some progressing to more advanced levels of learning. The connections between elementary schooling and the demands of daily life in ancient societies placed writing into particular 'subsets' of social and institutional life. People could (and did) exploit the skills they had learned in schools by drafting messages, compiling daily lists and accounts and testifying to the authenticity of documents by adding subscriptions or signatures.

We also know that significant percentages, in fact, the vast majority of all 1st-century Mediterranean societies were ignoran of 'letters', and unable to read or write, including some who had to deal with 'letters' on a fairly regular basis. The degrees of literacy, that is, the various possibilities along the spectrum of writing and/or reading skills, did not correlate directly with class, wealth and status. In other words, literary activities and literacy skills did not correlate.

In the Greco-Roman world the lack of (proficient) writing skills did not engender stigma nor disdain. Illiterate persons usually had recourse to a network of literates: the ubiquitous scribe, a relative, a friend, a slave in a nearby household.

The papyri from Roman Egypt inform us about the bradew gr a f o ont e $\sim$, 'those writing slowly' and the uhrog r $\alpha \varphi \varepsilon i{ }_{\zeta}$, 'substitute writers'. In these papyri we glimpse a world in which someone wrote on behalf of someone else, because that person either wrote slowly or did not know letters (Youtie 1971a, 1971b, 1975a, 1975b). Illiterates and semi-literates, in fact, manipulated the world of (Greek) writing quite effectively.

A remarkable illustration of this is Petaus, the kwmogr a mmat eur (town clerk) of Ptolemais Hormou and associated villages towards the end of the 2nd century CE. His signature is found on several documents, written in rigid, multi-stroke letters of varying size. However, we also have a sheet of papyrus on which Petaus repeatedly practised his signature. On this papyrus he wrote, P et au' kwmogra(mmat eu $\sim$ ) epidedwka (his name, title and a verb 'I have submitted'): the formula required to sign documents in his official capacity (P.Petaus 121). The papyrus shows that on his fifth attempt Petaus omitted the first vowel of the verb, which he continued to omit in his further seven attempts to practise the formula. Obviously he could not reproduce the formula correctly by heart and needed a model (i.e., the line immediately above) to copy. He clearly could not read his own writing with understanding. Yet Petaus knew where and how to sign documents and was quite capable of dealing with the demands of his office, in which he made use of professional scribes. ${ }^{3}$

The Apostle Paul might have been one of these 'slow writers' (Gal 6.11) and so, we can safely assume, were several other early Christian authors.

\section{'BY THE HAND OF A SCRIBE...'}

In the world of Greco-Roman writing another widespread and powerful force was at work. Even among the members of the elite and in scholarly circles who used writing with varying degrees of sophistication, practising writing as such was relegated to assistants, secretaries and servants. Although such individuals were undoubtedly educated their background and schooling socialised them to have distinct attitudes towards physical writing.

Learning to write in the ancient school was not governed by the same rules that regulated the process of learning to read. As a consequence, '... defining the relationship between writing and

3.On Petaus, see: Hanson 1991:171-174; Turner 1973:36-47; Youtie 1971b:239243. 
reading in Greco-Roman pedagogy is not a straightforward endeavor' (Cribiore 2001:176). ${ }^{4}$ Interaction between reading and writing was far less pronounced in Greco-Roman societies than it is among ourselves as 'writing was a separate skill' (Lane Fox 1994:144; cf. Cribiore 1996:176-178; Hanson 1991:179-183).

This particular attitude towards learning writing skills reflects deep-seated convictions about civilisation and achievement:

Quintilian and all the theorists and schoolmasters who have followed suit are silent on the subject of the differentiated practices of reading and writing. There is only one education worth writing about and that is liberal education. Its early stages are usually beneath notice. What counts is training to be an orator.

(Bloomer 1997:62)

Although a limited ability in writing was central to early or initial education, advanced education was associated with discrete ideas about literacy. After elementary education, specialised writing skills were taught by trades, crafts and slave schools. By contrast, advanced, 'liberal' education focused on providing a training in social distinction and in the linguistic skills suited for the fashioning of governors (Morgan 1998:226-234). This bifurcation was profound. After the initial exposure to teaching, the privileged boy's companion group changed from the free and slave children (the vernae) of the household to the liberi of the school (Bloomer 1997:60-61). His teachers changed from nurses, parents, freedmen and the people from his father's household to professional teachers and the world of his peers. Attending school meant rehearsing the social and sexual segregation of going to court or to elections, practising to speak in the forum (on behalf of others), and becoming adept carriers of the emblems of Roman civic life (Bloomer 1997:61; Morgan 1998:234-239).

When we study the writing exercises of these young people at school (the hermeneumata) ${ }^{5}$ we can see that they were learning to make distinctions, to categorise, to argue within a circumscribed field of characters, events, and solutions. They were learning not just how to speak, but who may speak and about what on whose behalf. Orally and in writing they were re-producing, and thereby positively identifying themselves with 'the cultural material and the ethical precepts' of their world, becoming active users of 'a vital marker of social status and power' (cf. Morgan 1998:198). They were learning about the inextricably connected social subordinations that constituted the Mediterranean world: where, in their perceptions and deliberations, to place various personae and what actions and sensibilities were appropriate to them. The linguistic and rhetorical expertise brought about by their schooling 'came to distinguish them from those with a craft literacy or vernacular or spoken linguistic skills' (Bloomer 1997:62).

The 'liberal' education about which Quintilian writes dealt with declamation, but the subjects of the declamatory speeches by the students were not neutral topics merely for the practice of technique. Declamation abounds with examples of those figures who prompt speech but will never be admitted to civil speech: freedmen, slaves, women. 'At the least, like other childhood games, declamation taught competition, rule following, and inculcated habits of stratification and distinction' (Bloomer 1997:69). In their actions as in their words, those boys were telling themselves and each other this is what we do and this is how we do it because this is who we are. Those who approved, their fathers, were affirming, you are one of us.

4.Our picture of Greco-Roman pedagogy is multifarious and incomplete at best. Recently scholars have started to reconsider and improve our understanding of primary and secondary education (Booth 1979; Kaster 1983). Noteworthy is that literate education was recognisably the same throughout the Empire, whether in Latin or Greek speaking areas (cf. Morgan 1998:66-67). In some cases the first Latin or Greek speaking areas (cf. Morgan 1998:66-67). In some cases the first elements of reading and writing must have been taught at home (Harris, 1989:307). 'Slaves were schooled in profitable literate trades. Poor boys pick in a portico or rented shop stall' (Bloomer 1997:61-62).

5.The hermeneumata, like the progymnasmata, are school texts (exercises) of the The hermeneumata, like the progymnasmata, are school texts (exercises) of the
Roman Period. See, among others, Bloomer (1997); Bradley (1994:26); Dionisotti (1982); Morgan (1998:64-65); and Webb (2001).
These habits shaped literary practices which often did not entail writing for themselves. Greco-Roman societies insisted on the 'institution' of scribes (rather than mass education). Advanced education (to become part of civil society) and specialised training (to write long texts) were considered distinct and very unequal aspects of society. ${ }^{6}$

The remarkable thing about all of this is the teachers who were not elite persons themselves but often slaves and mostly freedmen. This fact reminds us that we should beware the numbers trap: literacy is not merely about how many writing how much. Though individuals could (and did) write for, and by, themselves, but even when writing by oneself the attitudes, the expectations, the bodiliness of hierarchy and status sensitivities were present, implicating the 'natural and right order of things' (cf. Morgan 1998:268-270).

To write, even by one's own hand, entailed writing by the hand of a scribe.

\section{'FOR BEST WRITING, ... 25 DENARII...'}

Writing was a prized skill. The Edictum Diocletiani de pretiis rerum venalium was issued between 21 November and 31 December 301 in the name of the two augusti Diocletianus and Maximianus as well as in that of the caesares Constantius and Maximianus. The term 'edict' was derived from the expression dicunt in the praefatio (praef. 4), though in the text itself we find the terms lex (praef. 15) or statutum (praef. 15, 18, 19, 20). This 'law' was published across the Empire as part of a comprehensive administrative and financial reform whose primary goal was to secure provisions for the Roman army.

The praefatio names the occasion and purpose of the Edict, namely to set maximum prices as a way of controlling the avaritia of merchants and traders, who sometimes demanded eight times the usual amount for goods. Soldiers were particularly vulnerable, as they often had to spend a significant part of their pay on purchases from the marketplace. The Edict threatened capital punishment in cases of overcharging, illegal negotiations, or the hoarding of goods.

The Edict then continues with a list of foods, goods, and services, indicating more than a thousand maximum prices in denarii. In column 7, lines 39-41, we find the tariffs set for scribal work: 40 denarii for the preparation of a lot of four parchments, 25 denarii for 100 lines of best quality script, and 20 denarii for the same number of lines of second-grade quality script. ${ }^{7}$

An exploration of the world of 'payment for lines written' will help to explain writing costs and the values associated with writing. The following are exercises in historical imagination, consisting of some speculations as to what might have been involved in the production and copying of the works of New Testament 'authors'. Any description today must rely on generalisation, even though we know that the actual use of writing and writing technology in different contexts was quite diverse. Precision and certainty are therefore impossible. Technological application is continually re-imagined and re-deployed according to unique circumstances by creative human beings.

The limitations of our current documentation are severe. For instance, the Edictum Diocletiani does not specify what is meant by a "line" nor what is 'best' writing (scriptor in scriptura optima versus n. centum). Putting together the following general picture is intended simply to contribute to a background for discussions of the contexts of early Christian writings.

Copyists charged by the number of lines (stivoi), with books being priced accordingly (Ohly 1928:86-125; Haines-Eitzen

6.In the late Empire and Late Antiquity, and most noticeably in the Christian Empire, scribal and secretarial special skills started to become important means of rising to power and gaining status.

7.The Edict is accessible in Graser (1940). On the economic crisis that led to the Edict (and discussion of the problems interpreting it) see Corbier 2005; Drinkwater 2005; and Meißner 2000. 
TABLE 1

Estimated costs of copying some early Christian documents

\begin{tabular}{|c|c|c|c|c|c|}
\hline & Stiroia & $\begin{array}{r}\text { Drachmai } \\
\pm 225 \mathrm{CE}\end{array}$ & 'labour days’b & $\begin{array}{r}\text { Edict Diocl., 301, } \\
\text { denarii }^{\text {c }}\end{array}$ & $\begin{array}{r}\text { Ed.Diocl., skilled 'labour } \\
\text { days'd }\end{array}$ \\
\hline Matthew & 2560 & $51 / 2-71 / 2$ & $41 / 3$ & $512-640$ & 9 \\
\hline Luke & 2750 & $6-8$ & $42 / 3$ & $550-688$ & $91 / 2$ \\
\hline Acts & 2560 & $51 / 2-71 / 2$ & $41 / 3$ & $512-640$ & 9 \\
\hline John & 2020 & $4-6$ & $31 / 2$ & $404-505$ & 7 \\
\hline Mark & 1610 & $31 / 2-41 / 2$ & 3 & $322-403$ & $51 / 2$ \\
\hline Romans & 980 & $2-3$ & $12 / 3$ & $196-245$ & $31 / 3$ \\
\hline 1 Corinthians & 910 & $2-2^{2} / 3$ & $11 / 2$ & $182-228$ & 3 \\
\hline 2 Corinthians & 610 & $1 \frac{1}{3}-1 \frac{2}{3}$ & 1 & $122-153$ & 2 \\
\hline Galatians & 310 & $2 / 3-1$ & $1 / 2$ & $62-78$ & 1 \\
\hline Ephesians & 330 & $2 / 3-1$ & $1 / 2$ & $66-83$ & 1 \\
\hline Revelation & 1350 & $2^{3 / 4}-3^{3 / 4}$ & $21 / 3$ & $270-338$ & $42 / 3$ \\
\hline Hermas & 3650 & $71 / 2-11$ & 6 & $730-913$ & $12^{2 / 3}$ \\
\hline Ep. Barnabas & 880 & $13 / 4-21 / 2$ & $11 / 2$ & $176-220$ & 3 \\
\hline Hebrews & 715 & $1 \frac{1}{2}-2$ & $11 / 3$ & $144-180$ & $21 / 2$ \\
\hline 1 Timothy & 240 & $1 / 2-2 / 3$ & $1 / 2$ & $48-60$ & 1 \\
\hline Gs Thomas & 660 & $1 \frac{1}{2}-1^{3 / 4}$ & 1 & $132-165$ & 2 \\
\hline Didache & 300 & $2 / 3-3 / 4$ & $1 / 2$ & $60-75$ & 1 \\
\hline
\end{tabular}

Note: for easier calculation. The point is not absolute precision (which is impossible) but reasonable approximation. Statistics for NT $\sigma \tau 1 \alpha \alpha_{0}$ : Harris, J R 1883b:313-330; Metzger 981:38-40; 1987:298-299; Murphy-O'Connor 1995:120.

b. Calculated at five hours per day, writing two lines per minute.

c. At 20 and 25 den. per 100 lines respectively. Note that the information based on the Edictum Diocletiani is included for interest's sake only; in a way these are artificial prices. The Edict aims at providing maximum prices. It does not tell us what 'a line' entails. There is also a problem with the 'value' of Diocletian denarii. By the time of the Edict, the denarius was no longer in circulation.

d. The Edict sets the wage for an agricultural worker (operarius rusticus) at 25 denarii, with keep (pastus). The scribe's wage excludes support. The Edict sets the wage for various skilled workers (e.g., faber intestinarius, faber tignarius and carpentarius) at 50 denarii a day, including food (pastus). Scribal work probably fell in this category. For comparative purposes I include cost for daily support (taken at 12-15 denarii).

2002:87-88). In literary works, copyists maintained an average hexameter line, composed of (16) syllables with a total of about 36 letters per line (Harris, J R 1883a:137-145; Ohly 1928:22). ${ }^{8}$ For the purposes of this exercise I assume that the copying of early Christian documents followed the same standard, including Paul's letters (considering the exceptional length of his letters').

It is not a simple matter to use the Edictum Diocletiani as a guide to actual prices (if it can be used at all). An interesting alternative is Papyrus London Inv.2110, a fragmentary papyrus dating from the first half of the third century CE. It is an account of the receipts of a professional scriptorium (the text is published by Ohly 1928:88-90, 126-129). In this papyrus two prices are quoted, 47 drachmai for a book of 16600 lines and 13 drachmai for a book of 6300 lines. This gives us a range of price (for a long text and for a shorter text) of 0.283 to 0.207 drachmai per 100 lines.

Copying the Gospel of Luke at such prices would cost 5.7 or 7.9 drachmai. If we take the average $(0.245 \mathrm{dr}$. per 100 lines) the price would be $63 / 4$ drachmai (see Table 1). The account from the scriptorium makes clear that the cost of the papyrus is not included in the price for copying. ${ }^{10}$

The cost of papyrus is a notorious problem. ${ }^{11}$ Papyrus rolls were

8.It should be noted that Johnson found the average line length (a sort of 'norma' range) 'at roughly 13 to 24 letters per line' for prose texts among the Oxyrynchus bookrolls that he studied (Johnson 2004:114). There was 'no consistent correlation between width of column and letter counts' (Johnson 2004:114).

9.The typical papyrus letter is about one page (averaging about 100 words). Even literary authors, such as Cicero and Seneca, did not write letters as lengthy as Paul's (Richards 1991:213)

10.P.Lond.Inv. 2011, column 1 line 9 reads, up er grapt rwæet w'n a ut w'n bi bl iwn st ie wn indicating that the preceding item, costing 41 drachmai must be something other than the cost of copying, which must be the cost of the papyrus required (Skeat 1982:67).

11. Which cannot be properly dealt with here. See the discussion by Skeat (1995).
TABLE 2

Estimated costs of papyrus scrolls

\begin{tabular}{lrrrr}
\hline & LINES & COLUMNS & LENGTH, CM. & DRACHMAI \\
\hline Matthew & 2560 & 85 & 940 & $61 / 2$ \\
Luke & 2750 & 92 & 1010 & 7 \\
Acts & 2560 & 85 & 940 & $61 / 2$ \\
John & 2020 & 67 & 740 & 5 \\
Mark & 1610 & 54 & 590 & 4 \\
Romans & 980 & 33 & 360 & $21 \% 2$ \\
Pauline letters & 4450 & 149 & 1635 & 11 \\
Revelation & 1350 & 45 & 495 & $31 \% 2$ \\
\hline
\end{tabular}

produced in lengths of about 6 metres ( 20 sheets of $\pm 30 \mathrm{~cm}$ wide glued together), with a height of about 25 centimetres $^{12}$ (to fit comfortably on the 'knee') and sold in Egypt for about 4 drachmai a roll. ${ }^{13}$ If we take the estimates of lines (see Table 1) and use 30 lines per column, at an average width of 9 centimetres, ${ }^{14}$ to which intercolumn spacing should be added (2 centimetres), New Testament writings set on rolls would entail the costs indicated in Table 2.

These calculations can be compared with $\mathbf{P}^{45}$ (which is a codex) as a control. $\mathbf{P}^{45}$ has columns of writing of $16 \times 19$ centimetres $(\mathrm{w}$

12. The conventional estimate is 25 centimetres; the Herculaneum papyri has a standard height of 19 to 24 centimetres. Johnson shows that early Roman period scrolls are 19 to 25 centimetres high; in the later Roman era a height of between 25 to 33 centimetres came to dominate (Johnson 2004:141-143).

13. The price of 4 drachmai for an unused roll remained fairly constant during the first two centuries in Egypt (Bagnall 1995:13; Drexhage 1991:384-389; Harris, W.V.1989:195; Hedrick 2005:73; Lewis 1974:129-134).

14.Johnson (2004) found that the typical column width among literary papyri from Oxyrhynchus is about 6 centimetres, averaging about 24 letters. In my calculation a line is 36 letters, hence a column width of 9 centimetres. 
$\times \mathrm{h}$, per page); if we include intercolumnar space of 2 centimetres the gospels set on rolls would entail:

$\begin{array}{lll}\text { Matthew (49 columns) } & 49 \times 18=882 \mathrm{~cm} . \\ \text { Mark ( } 32 \text { columns) } & 32 \times 18=576 \mathrm{~cm} . \\ \text { Luke }(48 \text { columns) } & 48 \times 18=864 \mathrm{~cm} . \\ \text { John ( } 38 \text { columns) } & 38 \times 18 & =684 \mathrm{~cm} . \\ \text { Four Gospels, single scroll } & & =3006 \mathrm{~cm} .\end{array}$

Using $\mathbf{P}^{46}$ as comparative basis the Pauline Letters (including Hebrews) would transcribe onto a roll of 2806 centimetres. These calculations correlate adequately with those in Table 2.

Thus, a copy of Matthew (in the 2nd century) would probably have required handing over at least 12 drachmai, about 6 for the papyrus and 6 more for copying. Copies of Luke and Acts on a single scroll would have cost about 27 drachmai. Comparatively speaking, instead of a copy of the Gospel of Matthew, one could have bought 72 loaves of bread or 18 litres of wine. A cheap tunic (c it wn ) made by apprentices cost between 16 and 24 drachmai, a white shirt (for special occasions) about 40 drachmai, and a bath towel 3 drachmai 3 oboloi. ${ }^{15}$

The price of copies of early Christian texts cannot be seen as particularly exorbitant. What is more revealing is that during the 2nd century an 'average' six-person household required at least a thousand drachmai a year for food, clothing and housing just to survive (summarising Drexhage 1991:440-454). By the middle of the 2 nd century the average wage for a day-labourer was about 1 drachma 1 obol, which increased by about 3 to 5 oboloi $^{16}$ towards the 3rd century (Drexhage 1991:405).

When we turn to the origins of the New Testament writings the costs calculated in Table 1 are incomplete. Papyrus London 2110 indicates costs for copying an existing text and an author required more extensive assistance than just copying. Did a scribe contracted to perform secretarial work include the time spent on preparatory work in the cost of the final copy's number of stichoi? Probably not, if we consider the amounts listed in Table 1.

What was involved in writing a New Testament document? From the working methods of the two Plinys, Cicero and others, we learn that for longer works, including letters, writing began with note-taking which would be worked up into a draft copy, after which a proper version of the work was prepared, to be sent off to its prospective recipients (Dorandi 1991; 1993; cf. Botha 2009). The writing of a rough draft took relatively little time, whereas the refined version was written more carefully, typically on fine papyrus. The rough draft(s) would also entail composition, dictation, possible discussion, redirection and consultation of notebooks (e.g., notes kept by the author and/ or the scribe). ${ }^{17}$

Dictation, it is important to keep in mind, often played a role in the various aspects of authoring. ${ }^{18}$ Dictation probably was part of not only note-taking and composition, but of editing, compiling and publication.

15.The prices given are all from the second half of the second century, in Egypt. See Drexhage 1991, ad. loc. Szaivert \& Wolters (2005) has detailed price lists. However, such compilations should be used circumspectly, especially for translation into first-century values. We need to keep in mind that during the early Empire, . Egypt was mainly a closed currency area, and the tetradrachm was tariffed at 1

16.6 oboloi $=1$ drachma

17.Composition in memory - even for very long texts - is possible and was done; probably most Greco-Roman authors were quite practised at doing so (Botha 2005). Yet we have many indications of authors deliberately seeking advice from friends and/or employing correctors. 'Paul may have had a particularly retentive memory, but it would have been more in keeping with the ethos of his age to have noted, either personally or by a secretary, such items as he felt might be useful in his oral instruction and written communication' (Murphy-O'Connor 1995:36) - a description probably valid for other New Testament authors as well.

18.In fact, one of the defining characteristics of Greco-Roman literacy is the presence of dictation. Typically, authoring in antiquity entailed two different activities (at least) two different individuas. Espcilly for literary texts, accomplished by (at least) two diferent individuals. Especially for literary texts,

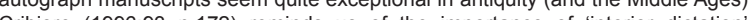
Cribiore (1996:93 n.172) rection us of the inportance of "interior dictation. n.247, 336; Johnson 2004:39-40; Skeat 1956; Small 1997:170-174.
We do not know, but I imagine writings such as the Gospel of Mark, Luke-Acts and letters such as 1 Corinthians or Romans were likely to have been completed in at least three phases: firstly, note-taking and basic composition; secondly, rough drafting, and thirdly, the final copy. These works were likely to have been written out, in various forms, at least three times.

By means of a few experiments I have established that I can copy a page of 30 lines (at about 36 letters per line), writing in capitals, in about ten minutes. A practised, motivated professional would easily be able to match or even improve on such a rate, that is, writing at three lines (stichoi) per minute. However, as I write with modern materials using a quality ballpoint pen (therefore without the need for having to dip the pen in ink or to sharpen the point) I would surmise that three lines per minute would most probably be the upper limit for writing done quickly, in the type of handwriting which Turner describes as informal round hand. ${ }^{19}$ The average over a period of time would, most likely, be closer to two lines per minute.

Writing with precision and attempting to achieve a calligraphic appearance was very difficult and almost impossible for me to do quickly. Even with considerable practice it was challenging to improve on one line per minute, though I think it safe to submit that an experienced professional could probably do about 1.5 lines per minute of formal mixed hand. ${ }^{20}$

A long time ago Eduard Stange suggested a tempo of about 1.5 lines per minute for Paul's secretary. ${ }^{21}$ That would seem to be a useful guideline for neat writing; that is, writing out a proper version ready for circulation. ${ }^{22}$

Though fast writing can keep up with slow dictation, it cannot do so for protracted periods. To take down a speech with some reliability absolutely requires some form of speedwriting or shorthand - as all secretaries and journalists working without modern recording devices know. ${ }^{23}$ Though longhand writing was certainly used to compose some early Christian texts, the role of scribes who were capable of speedwriting and/or shorthand must be considered.

Speedwriting can be done at more than twice the speed of longhand, due to using less letters and abbreviations. Speeds of up to 120 words a minute are possible for short periods of time, with speeds of 80 words a minute being regularly attained. However, speedwriting is nowhere near as fast as symbolic shorthand systems.

19. Turner classified literary hands of the first four centuries CE into three main groups: (1) Informal round hands; (2) Formal round hands; (3) Formal mixed hands (Turner \& Parsons 1987:20-21) 'The class of informal round hands is large .... It includes hands so quickly written as to be almost characterless - "nondescript" ...' (Turner \& Parsons 1987:21)

20.Turner's 'formal mixed' is similar to the 'severe' style of handwriting used in other papyrological handbooks (e.g., Kenyon 1899:75-76). The assumption is that New Testament authors did not publish in a 'formal round' hand which is almost instantly recognisable (from the generous size of their letters and the use of serifs or decorated roundels). It is, of course, possible that the New Testament authors published in a calligraphic hand, in something similar to 'biblical majuscule', which is not confined to the writing of biblical texts (it is a terminological relic). 'Of al

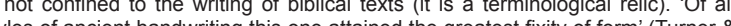
is Parsons 1987:22). For my purposes in the current article the calligraphic option is excluded from the account.

21.'Rechnen wir für die flüchtige Abschrift einer Seite des Nestleschen Testaments (ca. 30 Zeilen) bei Akzentloser Minuskelschrift mindestens 10 Minuten, für das paulinische Diktat derselben aber, das ja nicht onhe einzelne Wiederholungen und Stockungen abging, mindestens das Doppelte, also 20 Minuten, so ergibt das für das Diktat des Römerbriefes $111 \frac{1}{3}$ Stunde, des I.Korintherbriefes $101 / 3$, des Philipperbriefes $21 / 2$, aber auch noch für I.Thessalonicherbrief 21/3 Stunde' (Stange 1918:109).

22.Making use of the data collected by Dixon, Kurzman \& Friesen (1993), it can be calculated that handwriting, on average, requires 0.465 seconds per letter (in sentences in English, using cursive script) or about 17 seconds for a 36-letter line, equalling about 3 stichoi per minute.

23.Generally, the maximum possible writing rate is 40 words per minute, with the maximum possible speaking rate considered to be 200 words per minute (Gould $\&$ Boies 1978:1146). Of course, the notion of the 'speed' of speech is itself problematic (Wainschenker, Doorn \& Castro 2002) 
Speedwriting and shorthand were well-known in antiquity. Using symbols for letters, syllables, words and short phrases shmeiografioi (later called tacugrafioi), notarii and exceptores could easily take down speeches.

According to Plutarch (Cato Minor 23.3) the first speech recorded in this way was delivered by Cato on 5 December $63 \mathrm{BCE}$ demanding the death penalty for the Catilinarians. Plutarch adds that Cicero had scribes specially trained for the purpose of taking down speeches. ${ }^{24}$ Cicero's freedman and secretary, Tiro, ${ }^{25}$ devised a system of signs (notae) for prepositions and other short words, and then invented signs for endings (declinationes). These notae Tironianae were widely used in the imperial administration, as well as later by the Church.

Martial mentions both the shorthand scribe (notarius, 14.208) and the shorthand teacher (10.62.4).

Quick as speech is, the hand is quicker;

Before the tongue stops, the hand has finished.

(Martial Epigrams 14.208)

Quintilian notes the impact of the competent shorthand scribe:

The condemnation which I have passed on such carelessness in writing will make it clear what my views are on the luxury of dictation, which is now so fashionable. For, when we write even quickly the hand cannot follow the rapidity of our thoughts so we have time to think, whereas the presence of our amanuensis hurries us on, and at times we feel ashamed to hesitate or pause, or make some alteration, as though we were afraid to display such weakness before a witness. As a result, our language tends not merely to be haphazard and formless, but in our desire to produce a continuous flow, we let slip positive improprieties of diction, which show neither the precision of the writer nor the impetuosity of the speaker.

(InstOrat 10.3.19-20)

Seneca writes about the remarkable things invented by slaves (Epistulae 40.25): 'What about signs for words with which a speech is copied in writing, however rapid, and the hand follows the speed of tongue'. About his uncle, Pliny the Younger reports:

In his journeys ... he found leisure for this sole pursuit [continuing his studies]. A shorthand writer (notarius), with bookroll and tablets (pugillaribus), constantly attended him in his chariot, who, in winter, wore a particular sort of warm gloves, that the sharpness of the weather might not occasion any interruption to his studies; and for the same reason my uncle always used a sedan chair in Rome.

(Epistulae 3.5)

From papyri and wax tablets which were found in Egypt we learn about Greek shorthand. From the 2nd century onwards, examples of Greek shorthand and parts of manuals survive in large numbers. In these examples we find properly organised systems, composed of syllabaries and commentaries, as well as groups of words, arranged in fours or occasionally eights, with a sign attached to each, which had to be memorised (Milne 1934:3-6). Initially, such systems were practised only by slaves and freedmen trained as scribes (Teitler 1985:27-29, 31-34).

Was tachygraphy (in Greek) common during the first century? All indications are that it was. Cicero (in a letter to Atticus, 45 BCE) explicitly uses the Greek phrase dia; shmeiwn to refer to shorthand, indicating the existence of such systems (Cicero Ad Atticum 13.32). Cicero's son writes (to Tiro - Cic. Ad familiares

24.Plutarch also reports that Julius Caesar kept a slave 'who was accustomed to write from dictation', sitting next to him on his travels (Caes. 17.4-5).

25.Marcus Tullius Tiro, slave (born as a child of a war prisoner) and secretary of Cicero, who eventually manumitted him (in 53 BCE), was clearly a highly educated (in 53 BCE), was clearly a highly educated and gitted person who probably shaped Cicero's work and hentage to a remarkable extent. Yet, due to his status he will always remain a shadowy figure (McDermo 1972). McDermott (1972:272) doubts whether Tiro actually devised a shorthand system, but see Milne 1934:1; Teitler 1985:172-173.
16.21.8) to justify his less-than-sterling performance studying philosophy in Athens: 'But I beg you to see that a copyist (librarius) is sent to me as quickly as possible, most preferably a Greek (maxime quidem Graecus), for that will relieve me of a lot of trouble in writing out lecture notes' (the assumption being that a competent scribe could be found in Rome). Oxyrhynchus Papyri 4.724 (155 CE) is an apprenticeship contract with a shorthand teacher, the agreement entails a two-year training period. ${ }^{26}$

To visualise the kind of secretaries who could have been involved in the creation of the New Testament documents the following examples seem relevant. In 108 the slaves Sabinus and Diadumenus, both notarii of 'P. Dasumius Tuscus', were manumitted by testament in Rome (CIL 6.10229). Dating from the year 111, P.Oxyrynchus 44.3197 tells us that in Egypt the vo $\alpha \alpha$ optor Ammonas, Epaphrys, Agathys, Sarapas and Eucaerus, together with a large number of other slaves, were distributed among the heirs of a certain Ti. Julius Theon.

As there was no organising authority to determine the 'real' form of ancient shorthand writing, the modern debate about what should be and what should not be considered ancient shorthand and whether dictation was syllabatim or viva voce seems somewhat fruitless. Clearly, both approaches were practised as situation proscribed and possibilities became available. ${ }^{27}$ In P.Michigan 2.121, dated to $42 \mathrm{CE}$ the scribe uses 'frequent phonetic spellings, and a great deal of abbreviation' (Turner \& Parsons 1987:100). Scribes, we can be very certain of, made use of various forms of speedwriting.

Obviously, not all scribes were stenographers, though notarii/ not avioi often were both scribes and shorthand writers. What exactly distinguished them from other writers such as librarii,

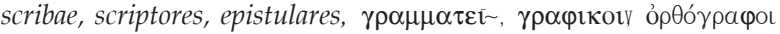

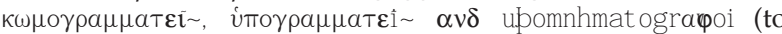
name but some of the crafts/functions) we do not know, though they probably shared many of the same skills and training. One implication seems fairly certain: the production of a literary text involved several people during the 'authoring' process.

Very likely most early Christian authors employed a variety of secretarial skills for their writings. Some general considerations support this view. Scribal skills often included more than just writing. "The training of slaves in clerical skills to increase their value was common' (Booth 1979:11). ${ }^{28}$ Precisely such skills made the difference between whether one made use of scribes, or wrote oneself. Knowing how to read and write did not make the specialist role of scribes superfluous. Also, the very speed with which early Christian literature spread through the Roman Empire must have been due, in part at least, to the successful participation of competent scribes in the movement.

With all these considerations in mind, some possibilities about the investment of time for the New Testament writings can be calculated. (Note that the focus is on the writing, the time spent on research, composition and rethinking is left out of consideration.)

Performing the Gospel of Mark requires about seventy-five minutes, the Letter to the Romans about forty-five; it can be assumed that dictation at normal speech speed would require about the same amount of time. However, composing, formulating and consultation of notes inevitably intruded, so that note-taking during the first stage, even in shorthand, would

26. The earliest indication of Greek tachygraphy among the papyri dates from the late first century (Giovè Marchioli \& Menci 1998).

27.Dictation syllabitim is self-evident See for example, Seneca Epistulae 40.10; Bah (1966:470-471). Dictation viva voce: secretaries recorded speeches in the Senate (cf. Se cf. Seneca Epistulae 40.25; Suetonius Divus Titus 3.2; Seneca Apocolocyntosis $9.2)$

28.An aspect also emphasised by Mohler (1940) and Forbes (1955). On the presence of slaves in Roman education: Bloomer (1997:61-62). Opportunities for slaves with of slaves in Roman education: Bloomer (1997:61-62). Opportunities for slaves with
literate training are discussed by Joshel (1992:46-91) and Treggiari (1969:123). 
TABLE 3

The time needed for writing some early Christian texts

\begin{tabular}{|c|c|c|c|c|c|c|}
\hline & $\Sigma$ TIṇXOI & $\begin{array}{r}\text { PERFORM } \\
\text { (MINUTES) }\end{array}$ & $\begin{array}{r}\text { NOTETAKING }^{\dagger} \\
\text { (HOURS) }\end{array}$ & $\begin{array}{r}\text { DRAFT COPYg } \\
\text { (HOURS) }\end{array}$ & $\begin{array}{r}\text { REVISED COPYh } \\
\text { (HOURS) }\end{array}$ & $\begin{array}{l}\text { AT LEAST- } \\
\text { PROBABLY' }\end{array}$ \\
\hline Matthew & 2560 & 125 & 3 & 23 & 29 & 5-11 days \\
\hline Luke & 2750 & 130 & 3 & 25 & 31 & $6-12$ days \\
\hline Acts & 2560 & 120 & 3 & 23 & 29 & 5-11 days \\
\hline John & 2020 & 100 & 3 & 19 & 23 & 4-9 days \\
\hline Mark & 1610 & 75 & 2 & 15 & 18 & $3-7$ days \\
\hline Romans & 980 & 50 & $11 / 2$ & 9 & 11 & $2-5$ days \\
\hline 1 Corinthians & 910 & 50 & $11 / 2$ & 8 & 10 & $2-4$ days \\
\hline 2 Corinthians & 610 & 33 & 1 & 6 & 7 & $1-2^{1 / 2}$ days \\
\hline Galatians & 310 & 16 & $3 / 4$ & 3 & 4 & $1 / 2-11 / 2$ days \\
\hline Ephesians & 330 & 22 & $3 / 4$ & 3 & 4 & $1 / 2-11 / 2$ days \\
\hline Revelation & 1350 & 60 & $11 / 2$ & 12 & 15 & $2 \frac{1}{2}-6$ days \\
\hline Shepherd of Hermas & 3650 & 180 & 7 & 34 & 41 & $7-16$ days \\
\hline Epistle of Barnabas & 880 & 50 & $11 / 2$ & 8 & 10 & $1 \frac{1}{2}-4$ days \\
\hline Hebrews & 715 & 35 & 1 & 7 & 8 & $1 \frac{1}{2}-3$ days \\
\hline $1 \mathrm{Tim}$ & 240 & 15 & $1 / 2$ & 2 & 3 & $1 / 2-1$ day \\
\hline Gospel Thomas & 660 & 35 & 1 & 6 & 8 & $1 \frac{1}{2}-3$ days \\
\hline Didache & 300 & 16 & $3 / 4$ & 3 & 4 & $1 / 2-11 / 2$ days \\
\hline
\end{tabular}

Note:

e. My estimates, based on reading the Greek text aloud, and some experiments with performed NT texts.

f. Performance time $\times 1.5$, assuming the shorthand recording of the dictation (performing the text), plus half that period of time.

g. Writing at 2 lines per minute, and adding time for reading, consultation of notes and preparation of writing materials (estimated at equivalent to reading the complete text).

h. Writing at 1.5 lines per minute.

A text could hardly have been written out in usable format more quickly than might have been taken for a 'draft' copy (column 5 ), hence that figure is the 'at least' time required. Realistically, the text was taken down, written out and neatly rewritten, hence the 'probably', which represents the sum of the figures in columns 4,5 and 6 .

have taken at least one-and-a-half times longer, though possibly twice or even three times as long. ${ }^{29}$

What must further be taken into account is the time needed by the scribe(s) to prepare the papyrus sheets, score the lines on the sheets, prepare the ink and pens, arrange note-books and other such activities.

How many hours should count as a working day? I would suggest a working day of five hours of actual writing. This is to realistically account for availability of daylight, weather conditions and all sorts of (inevitable) interruptions. ${ }^{30}$ Table 3 presents some calculations with regard to time involved in writing basic versions of some early Christian literature.

To factor in the cost of papyrus at the time of writing these documents a price of 5 denarii per scroll can be used (transport costs increased the price of papyrus outside Egypt). If Mark wrote in Rome he most probably kept a scribe or two busy for about seven days and consumed at least two rolls of papyrus (10 denarii). Luke would have used about three-and-a-half rolls (17 denarii) and kept a few scribes busy for twelve days.

It is doubtful whether early Christian authors actually paid for their papyrus and scribes. They probably had patrons supplying writing materials and scribes, or, as at least in the case of Paul, scribes probably gave their assistance voluntarily.

29. The assumption is that there is some interaction between author and scribe(s). Composition by speaking is faster than composition by dictation, which is faster than composition by writing (about $20 \%$ faster, if modern standards are any indication: see Gould \& Boies 1978:1146). Interestingly, involvement in language production (i.e., composition) affects the speed and legibility of handwriting; conversely, focus on speed (legibility) impacts on understanding and recall (Brown et al. 1988; Van Galen 1991:179).

30.Secretaries working in British parliamentary committees during the 1880 s worked in pairs taking turs at shorthand note-taking and longhand text prepartion. Apin pairs taking turns at shorthand nole-taking and longhand text preparation. Apparently they maintained two to three hours of continuous shorthand witing, when " turn of fast wiling was over, the longhand bouts of about two hours with overall shifts lasting about 5 hours. Written (final) manuscripts were produced at about 47 words per minute (cf. 'The shorthand congress' 1887:195).
Whatever the case might have been, the creation of most early Christian documents reflects dedication and commitment. Though nothing wildly exorbitant, we are once again reminded of a fairly serious investment of resources.

More to the point, we are reminded of the many hands involved in the writing of the New Testament and early Christian literature. Producing literary texts was in many ways labour intensive. Also, we are reminded that the past is like a different country. To take Paul as an example, an exercise like this serves

... to remind the reader that everything took a lot longer in Paul's day. We need to slow down radically if we are to appreciate the rhythm of his life. We tend to imagine that travel and communications were just somewhat slower than today. In fact, there was a huge quantitative difference, which had a great impact on the quality of communication.

(Murphy-O'Connor 2004:viii; cf. Hartman 1986:138)

\section{PUPIL AND FREEDMAN AND ASSISTANT IN HIS LITERARY WORK..}

This is how Aulus Gellius describes Marcus Tullius Tiro, ex-slave of Cicero: 'the pupil and freedman and an adiutor in [Cicero's] literary studies' (Noctes Atticae 13.9.1). Authors, we know, not only dictated their works to scribes but also made use of them for note-taking, editing, proofreading, correcting, reading, and research. This raises an interesting question: who wrote what?

The scribe, the literate slave, might have been used as a mere copyist, just a means to get words onto papyrus, but more often than not the scribe was secretary, research assistant, reader and messenger. He (or she) ${ }^{31}$ might even have been a co-author. Gellius had a high respect for Tiro - he mentions Tiro's 'care

31.We know less about the literacy education of girls than we would like to know - a telling fact in itself - but there is some evidence of the existence of female cribs. Teitler (1985:31-32) refs to the only two femate scribes. Teller (1985.31-32) refers to the only two female stenographers known fom anticuly, there were also female calligraphers (Heins discus who atended schools probably learne Girls who attended schools probably 'learned reading, writing, and perhaps reciting as a mimicry of male behavior' (Bloomer 1997:75). 
and learning' (Noct. att. 1.7.1) — though he sometimes missed little things:

Therefore I am not so much surprised that Marcus Tullius erred in that matter, as that it was not noticed later and corrected either by Cicero himself or by Tiro, his freedman, a most careful man, who gave great attention to his patron's books.

(Noct. att. 15.6.1-2)

Cicero refers to Tiro frequently in his letters, remarking on how useful he is to him for studies and literary work (e.g., Epistulae ad Atticum 7.5 ${ }^{32}$. Tiro's duties included taking dictation, deciphering Cicero's handwriting, revising and rewriting as well as managing the copying of texts. He probably authored several books himself. Aulus Gellius says, '[Tiro] wrote several books on the usage and theory of the Latin language and on miscellaneous questions of various kinds' (Noct. att. 13.9) and Plutarch cites him as a source for incidents in Cicero's life (Plutarch Cicero 41, 49).

Clearly, the scribe, the one wielding the pen, was more than just an instrument.

We cannot know in how many steps an author's work progressed or to what extent further readings and additional research and/ or consultations resulted in actual reworkings of a text. We do know that material was noted in the margins of the previously collected parts or added to the verso of the scroll. Various supplementary notes, and linguistic or stylistic improvements were included either on the margins and on the empty places of the recto or on the verso. Such insertions and additions were not made by the author himself but written down by a scribe or by the professional di or qwt $h \forall$ (corrector).

Often the secretary was entrusted with the responsibility for writing up the text from incomplete notes. Authors regularly left considerable scope to their secretaries; either on purpose, or due to rapid dictation, or because often only an outline or draft was provided. The line between editing and co-authorship is extremely difficult to draw.

If one writer excerpts or copies portions of another's work, but adds comments, supplements, appendices or insertions - or subtracts or epitomizes - then whether we regard the 'new' work thus produced as distinctively a different document in its own right, or as a 'new edition' or adaptation of the old, becomes a matter of degree only.

(Hall 1996:412-413)

The various roles assistants/scribes played in 'writing' a text, which are not unknown in New Testament scholarship, have drawn mostly the attention of Pauline scholarship. Usually, there is an insistence on distinguishing between a co-author and an amanuensis. Discerning such a difference is difficult, though Can we discover the different contributions of copying, editing and re-writing?

In cases of deliberate co-authorship various options present themselves ( $c f$. Prior 1989:39-50). The authors may have considered the substance of the letter individually, and then gone over the general plan of what they were to compose, or perhaps suggested the style and expression which they had separately chosen while thinking about the message before collaborating towards an agreed content and form.

Richards (1991:15-67) gives a useful overview of the use of a secretary in the Greco-Roman world. He notes that secretarial assistance was common, but that the role a secretary played varied greatly, depending on the degree of control he had over the content, style and/or form of a letter. Richards classifies the various roles of a secretary into four broad categories. (1) When the secretary functioned as a 'recorder', he would write

32.'I see that you are interested about Tiro. Though he is serviceable to me in thousand ways, when he is well, in every department of my business and my studies, yet my anxiety for his recovery is founded on his own kindness and high character, rather than on my convenience. the letter exactly as it was dictated by the author. (2) When the secretary served as an 'editor', he would make extensive notes of the author's dictation to be used later composing a final draft. The secretary's personal contribution consisted of relatively minor decisions about syntax, vocabulary, and style. (3) When the secretary worked as a 'co-author', the same type of procedure would be followed as in an editorial role except that the secretary's contribution would be greater. (4) When the secretary functioned as a 'composer', he would construct a letter on behalf of the author without receiving instructions as to its specific contents. Secretaries/scribes probably played similar roles in the writing of literary texts.

A related question is whether an author assumed full responsibility for the content and form of a book. The answer probably depended on circumstances, though 'the scribe' must have been a handy excuse in cases of unpleasant and awkward communications. Such excuse making is a noted feature of slave societies: 'Blaming the slave was a convenient way of avoiding embarrassment' (Fitzgerald 2000:58).

As an approach to understanding the textual characteristics of the gospels and especially the synoptic problem, or Acts and Revelation, little attention to possible roles of secretarial assistants and scribal options has been paid by New Testament scholars.

Given the limitations of our evidence, answers to our questions is almost impossible. Yet, most of the answers to our questions regarding gospel origins and the enscripturation of traditions simply ignore the material aspects of ancient literacy.

Recently Kim Haines-Eitzen (2002) has shown the importance of scribes in the production, reproduction and interpretation of early Christian texts. She argues that early Christian scribes were not only copyists but also the creators and users of texts who not only conserved texts but also modified them in accordance with their own theological knowledge and proclivities. Is it not possible that the very origins of Christian writings lie among such (small) groups of itinerant and marginal scribes? The very anonymity of most early Christian literary texts points in this direction.

Be that as it may, there is a fateful reason why we know so little about the contributions that were made by scribes and secretaries to ancient works.

\section{THE MASTER'S VOICE ...}

The key to understanding Greco-Roman literacy is often described as the 'living voice'. Can we be a bit more precise about that 'voice'?

In his Rethinking writing, Roy Harris notes that 'how literate people view writing is often colored by their opinions concerning literacy and their own status as literate members of the human race' (Harris 2000:ix). He wants us to rethink writing in a broad sociohistorical context. His concerns are with the limitations and problems that have to do with functional or utilitarian literacy, though his insight that what one thinks writing is as crucial to how one understands literacy, is important (cf. Harris 2000:x).

When we look at ancient manuscripts and visualise the pen making the markings in ink and we consider the hand holding the pen: how do we see the body behind the hand? The hands that held the pens that wrote the texts were the hands of stooped bodies, sitting low down. These were bodies looked upon, looked down on by authors and patrons and even clients.

The hands that made those artifacts, handled them, wrote on them, corrected them, took care of them, were the hands of subservient persons.

We, today, look at these writings as instruments by means of which to lever our way into 'the minds' of authors. The 'text' is a surrogate or extension of a 'noble mind'. I would like to prompt 
us to consider literacy not as a window into disembodied verbal worlds and especially not to treat the artefacts of inscription as separate from actual persons, settings and communicative modalities.

To adopt a more theoretical tone, ${ }^{33}$ we should rather dare to visualise the interplay of structure and construction, of history and agency. We should consider what can and what should be said about the institutional contexts that gave distinct (i.e., GrecoRoman) significance to the literacy events that we call the New Testament and early Christian texts.

Writing in Greco-Roman times was part of a system which was influenced by such considerations as writing materials and the provision of technical support available in society. Such aspects, in turn, were extended by cultural factors such as mores which forbade upper-class members of society from being physically lower than lower-class individuals. Scribal duties, which required at least some bending, were relegated to people low enough in class to stoop.

Seneca may be defending the virtues of the properly trained philosophical (Stoic) mind, but he affords us a glimpse of how writers (scribes) were seen. He describes several useful things that have been invented, among them

... our signs for whole words, which enable us to take down a speech, however rapidly uttered, matching speed of tongue by speed of hand. All this sort of thing has been devised by the lowest grade of slaves. Wisdom's seat is higher; she trains not the hands, but is mistress of our minds.

(Seneca Younger, Letters 90.25-26)

He does not deny slaves and scribes the possession of intelligence and great skill, as he lists in detail many astounding achievements of lower-class people, but he insists that

[although both the hammer and the tongs ]... were invented by some man whose mind was nimble and keen, but not great or exalted. The same holds true of any other discovery which can only be made by means of a bent body and of a mind whose gaze is upon the ground.

(Seneca Younger, Letters 90.10)

We like to think of education (specifically reading and writing) as forces of liberation and class-transcending powers. Education, however, can also be hierarchical and cause division. In the Greco-Roman world the

highest level of linguistic and literary achievement came to those who completed the secondary stage of education and then studied with a teacher of rhetoric. Greco-Roman culture regarded the welldelivered and persuasive speech as the most characteristic feature of civilized life. In contrast to our own culture, linguistic skill focused on oral speech; the written word was secondary, derived from primary rhetoric.

(Stowers 1986:33-34)

In addition, in that world writing, in its wider sense, was considered labour.

The laborious is clearly not the noble. There are many things that are laborious, which you would deem not appropriate to boast of having done; unless, you actually thought it glorious to copy out stories and whole speeches in your own hand.

(Rhetorica ad Herennium 4.6)

The copyists and the literary scribes, the amanuenses and the librarii, the correctors and the calligraphers were all either slaves or freedmen. That the scribes who took down dictation, who corrected and improved texts, and who were responsible for copying and distributing books were from the slave and freed classes should not surprise us, and we should not forget the stigma that was attached to such labour. 'No matter how indispensable these scribes were, they were not members of the upper classes' (Haines-Eitzen 2002:31).

33. The useful conceptual term in this regard is 'practice', reflecting the legacy of thinkers such as Marshal Sahlins, Raymond Williams, Anthony Giddens, Michel Foucault, and Pierre Bourdieu.
In the physical act of writing out literary texts there was a social dynamic at work, and the (scribal) writer need not to have been a slave de jure to be caught up in the social, moral and even aesthetic value judgements enacted by one who was a dictator and one who 'took dictation'.

Mastery is more than a metaphor or some idealised hope or trope of the governing class. At stake is not so much a proscription of who may read and write (as a participant in physical activities), but an expectation of who reads and writes in what capacity: '... the maintenance of subordinates was inextricably connected to practices of reading and writing, indeed to the development of upper-class speech' (Bloomer 1997:60). A scribe did not just write a text, but performed a code; an almost ceremonial act necessarily circumscribed by the roles of superior and inferior.

The creation of early Christian literature came about through the application of skills and practices typically employed elsewhere, and by doing so the New Testament and other early Christian authors not only advanced the spread of the Jesus movement, but also gave it a remarkable 'scriptural' identity.

We should take care not to romanticise these subordinates using their skills to promote an alternative society. In their emulation of literary practices powerful distinctions were still at work. It could not have been otherwise. They may have criticised power and evoked alternatives to abuse of power, but their writings also reflect claims to power. Inevitably they engaged in a process of organising and negotiating and establishing power and control. As in the contact with the influential classes where elite and non-elite are to a degree complicitous (Bloomer 1997:76) by maintaining society, the early Christian scribes were inscribing who may speak and about what; who will be the 'competent' speaker and who will be the 'proper listener'.

\section{CONCLUDING REMARKS}

This discussion has as its aim the consideration of GrecoRoman writings as events, as situated 'doings', where the issue is not a binary contrast between literacy and orality, not about people just decoding or encoding text, but rather texts as socially embedded and culturally mediated performances. The participants in such events were socialised into and enacted particular views of writing. We need to look at ancient writing as structured practices where people took roles in these events, which constituted part of larger-purpose endeavours. In brief: literary practices need to be seen as part of social practices.

People do things for a reason; people have purposes. Literacy serves other purposes. In general, people do not read in order to read, or write in order to write; rather, people read and write in order to do other things, in order to achieve other ends. ...The importance of viewing reading and writing in terms of social practices is that we see the purpose behind the activities; we also see how intertwined the written word is with other forms of communication, especially spoken language.

(Barton 1991:8)

The explorations undertaken in this study have been done for illustrative purposes to gain some sense of values and implicit and explicit costs involved with the making and distribution of early Christian literature. We have seen that writing was performed by seated individuals, who rested a papyrus roll or sheet on their lap, using their knee to support the material on which they wrote. Producing literary texts required several people, and necessitated extensive material support and settings where ample allocation of time could be made. Most of all, writing in Greco-Roman times reflected the enactment of socially established values and attitudes marked by servitude.

Woolf (2000:875) argues that '...the study of Roman writing practices sheds new light on many aspects of early imperial society, economy, religion and government, and suggests new connections between them'. The current study should serve as a small contribution in this regard. 


\section{REFERENCES}

Bagnall, R.S., 1995, Reading papyri, writing ancient history, Routledge, London.

Bahr, G.J., 1966, 'Paul and letter writing in the first century', Catholic Biblical Quarterly 28, 465-477.

Barton, D., 1991, 'The social nature of writing', in D. Barton \& R. Ivanič (eds.), Writing in the community, pp. 1-13, SAGE, London.

Bloomer, W.M., 1997, 'Schooling in persona: Imagination and subordination in Roman education', Classical Antiquity 16(1), 57-78.

Booth, A.D., 1979, 'The schooling of slaves in first-century Rome', Transactions of the American Philological Association $109,11-19$

Botha, P.J.J., 2005, 'New Testament texts in the context of reading practices of the Roman Period: The role of memory and performance', Scriptura 90, 621-640.

Botha, P.J.J., 2009, 'Authorship in historical perspective and its bearing on New Testament and early Christian texts and contexts', Scriptura 101, 1-25.

Bradley, K.R., 1994, Slavery and society at Rome, Cambridge University Press, Cambridge.

Brown, J.S., Brown, T.L., Carr, T.H. \& McDonald, J.L., 1988 'Adapting to processing demands in discourse production: the case of handwriting', Journal of Experimental Psychology: Learning, Memory, and Cognition 14(1), 45-59.

Černý, J., 1952, Paper and books in ancient Egypt, London, University College (H.K. Lewis).

Cook, C., Burgess-Limerick, R. \& Papalia, S., 2004, 'The effect of upper extremity support on upper extremity posture and muscle activity during keyboard use', Applied Ergonomics 35, 285-292.

Corbier, M., 2005, 'Coinage, society and economy', in A.K. Bowman, P. Garnsey \& A. Cameron (eds.), The Cambridge Ancient History: Vol. 12.2, The Crisis of Empire, A.D. 193-337, pp. 397-439, Cambridge University Press, Cambridge.

Cribiore, R., 1996, Writing, teachers, and students in Graeco-Roman Egypt, Scholars Press, Atlanta.

Cribiore, R., 2001, Gymnastics of the mind: Greek education in Hellenistic and Roman Egypt, Princeton University Press, Princeton.

Dionisotti, A.C., 1982, 'From Ausonius' schooldays? A schoolbook and its relatives', Journal of Roman Studies 72, 83125.

Dixon, R.A., Kurzman, D. \& Friesen, I.C., 1993, 'Handwriting performance in younger and older adults: Age, familiarity, and practice effects', Psychology and Aging 8(3), 360-370.

Dorandi, T., 1991, 'Den Autoren über die Schulter geschaut: Arbeitsweise und Autographie bei den antiken Schriftstellern', Zeitschrift für Papyrologie und Epigraphik $87,11-33$.

Dorandi, T., 1993, 'Zwischen Autographie und Diktat: Momente der Textualität in der antiken Welt', in W. Kullmann \& J Althoff (eds.), Vermittlung und Tradierung von Wissen in der griechischen Kultur, ScriptOralia, vol. 61, pp. 71-83, Gunter Narr Verlag, Tübingen.

Drexhage, H.-J., 1991, Preise, Mieten/Pachten, Kosten und Löhne im römischen Ägypten bis zum Regierungsantritt Diokletians, Scripta Mercaturae Verlag, St. Katharinen.

Drinkwater, J., 2005, 'Maximinus to Diocletian and the "crisis"', in A.K. Bowman, P. Garnsey \& A. Cameron (eds.), The Cambridge Ancient History: Vol. 12.2, The crisis of empire, A.D. 193-337, pp. 28-66, Cambridge University Press, Cambridge.

Duncan-Jones, R., 1994, Money and government in the Roman Empire, Cambridge University Press, Cambridge.

Fitzgerald, W.C., 2000, Slavery and the Roman literary imagination, Cambridge University Press, Cambridge.

Forbes, C.A., 1955, 'The education and training of slaves in antiquity', Transactions and Proceedings of the American Philological Association 86, 321-360.
Giovè Marchioli, N. \& Menci, G., 1998, 'Tachygraphie', in H. Cancik \& H. Schneider (Hrsg.), Der neue Pauly: Enzyklopädie der Antike, Altertum, vol. 11, pp. 1205-1208, Verlag J.B. Metzler, Stuttgart.

Gould, J.D. \& Boies, S.J., 1978, 'Writing, dictating, and speaking letters', Science 201(4361), 1145-1147.

Graser, E.R., 1940, 'The Edict of Diocletian on maximum prices', in T. Frank (ed.), An Economic Survey of Ancient Rome: Vol. 5 Rome and Italy of the Empire, pp. 305-421, Johns Hopkins Press, Baltimore.

Haines-Eitzen, K., 1998, 'Girls trained in beautiful writing: Female scribes in Roman antiquity and early Christianity', Journal of Early Christian Studies 6(4), 629-646.

Haines-Eitzen, K., 2002, Guardians of letters: Literacy, power, and the transmission of early Christian literature, Oxford University Press, Oxford.

Hall, L.G.H., 1996, 'Hirtius and the Bellum Alexandrinum', Classical Quarterly 46(2), 411-415.

Hanson, A.E., 1991, 'Ancient illiteracy', in J.H. Humphrey (ed.), Literacy in the Roman World, pp. 159-198, Journal of Roman Archaeology, suppl. ser., no. 3, University of Michigan, Ann Arbor.

Harris, J.R., 1883a, 'Stichometry', American Journal of Philology 4(2), 133-157.

Harris, J.R., 1883b, 'Stichometry. Part II', American Journal of Philology 4(3), 309-331.

Harris, R., 2000, Rethinking writing, Athlone, London.

Harris, W.V., 1989, Ancient literacy, Harvard University Press, Cambridge, MA.

Hartman, L., 1986, 'On reading others' letters', Harvard Theological Review 79, 137-146.

Hedrick, C.W. Jr., 2005, Ancient history: Monuments and documents, Wiley-Blackwell, Oxford.

Johnson, W.A., 2004, Bookrolls and scribes in Oxyrhynchus, University of Toronto Press, Toronto.

Joshel, S.R., 1992, 'Work, identity and legal status at Rome', in J.P. Hallett \& M.B. Skinner (eds.), Roman Sexualities, University of Oklahoma Press, Norman.

Kaster, R.A., 1983, 'Notes on "primary" and "secondary" schools in late antiquity', Transactions of the American Philological Association 113, 323-346.

Kenyon, F.G., 1899, The palaeography of Greek papyri, Clarendon, Oxford.

Lane Fox, R., 1994, 'Literacy and power in early Christianity', in A.K. Bowman \& G. Woolf (eds.), Literacy and Power in the Ancient World, pp. 126-148, Cambridge University Press, Cambridge.

Lewis, N., 1974, Papyrus in classical antiquity, Clarendon, Oxford.

Mack, B.L., 1988, A myth of innocence: Mark and Christian origins, Fortress Press, Philadelphia.

Marcus, M., Gerr, F., Monteilh, C., Ortiz, D.J., Gentry, E., Cohen, S. et al, 2002, 'A prospective study of computer users, II: Postural risk factors for musculoskeletal symptoms and disorders', American Journal of Industrial Medicine 41, 236249.

McDermott, W.C., 1972, M. Cicero and M. Tiro, Historia: Zeitschrift für Alte Geschichte 21(2), 259-286.

Meissner, B., 2000, 'Über Zweck und Anlaß von Diokletians Preisedikts', Historia: Zeitschrift für Alte Geschichte 49, 79_ 100.

Metzger, B.M., 1968, 'When did scribes begin to use writing desks?', in Historical and Literary Studies: Pagan, Jewish, and Christian, pp. 123-138, Brill, Leiden.

Metzger, B.M., 1981, Manuscripts of the Greek Bible: An introduction to Greek palaeography, Oxford University Press, Oxford.

Metzger, B.M., 1987, The canon of the New Testament: Its origin, development, and signficiance, Clarendon Press, Oxford.

Milne, H.J.M., 1934, Greek shorthand manuals: Syllabary and commentary, Egypt Exploration Society, London.

Mohler, S.L., 1940, 'Slave education in the Roman Empire', Transactions and Proceedings of the American Philological Association 71, 262-280. 
Morgan, T., 1998, Literate education in the Hellenistic and Roman worlds, Cambridge University Press, Cambridge.

Murphy-O'Connor, J., 1995, Paul the letter-writer: His world, his options, his skills, Liturgical Press, Collegeville.

Murphy-O'Connor, J., 2004, Paul: His story, Clarendon, Oxford.

O'Sullivan, P., Dankaerts, W., Burnett, A.F., Straker, L., Bargon, G. \& Maloney, N., 2006, Lumbopelvic kinematics and trunk muscle activity during sitting on stable and unstable surfaces, Journal of Orthopaedic and Sports Physical Therapy $36,19-25$.

Ohly, K., 1928, Stichometrische Untersuchungen: Beiheft zum Zentralblatt für Bibliothekswesen, vol. 61, Otto Harassowitz, Leipzig.

Parássoglou, G.M., 1979, ‘Dexia; cei;r kai; govnou: some thoughts on the postures of the ancient Greeks and Romans when writing on papyrus rolls', Scrittura e Civiltà 3, 5-21.

Parássoglou, G.M., 1985, 'A roll upon his knees', Yale Classical Studies 28, 273-276.

Prior, M., 1989, Paul the letter-writer, JSNT, suppl. ser., Sheffield Academic Press, Sheffield.

Rempel, D.M., Krause, N., Goldberg, R., Benner, D., Hudes, M. \& Goldner, G.U., 2006, 'A randomised controlled trial evaluating the effects of two workstation interventions on upper body pain and incident musculoskeletal disorders among computer operators', Occupational Environmental Medicine 63, 300-306.

Richards, E.R., 1991, The secretary in the letters of Paul, WUNT 2.42, Mohr, Tübingen.

'The shorthand congress', 1887, Science 10(246), 194-195.

Skeat, T.C., 1956, 'The use of dictation in ancient bookproduction', Proceedings of the British Academy 42, 179-208.

Skeat, T.C., 1995, 'Was papyrus regarded as "cheap" or "expensive" in the ancient world?', Aegyptus 75, 75-93.

Skeat, T.C., 2004, 'The length of the standard papyrus roll and the cost-advantage of the codex', in J.K. Elliott (ed.), The Collected Biblical writings of T.C. Skeat, pp. 65-70, Brill, Leiden. (Original work published 1982).

Small, J.P., 1997, Wax tablets of the mind: Cognitive studies of memory and literacy in classical antiquity, Routledge, London.

Stange, E., 1918, 'Diktierpausen in den Paulusbriefen', Zeitschrift für die neutestamentliche Wissenschaft 18, 109-117.
Stowers, S.K., 1986, Letter writing in Greco-Roman antiquity, Westminster Press, Philadelphia.

Szaivert, W. \& Wolters, R., 2005, Löhne, Preise, Werte: Quellen zur römischen Geldwirtschaft, Wissenschaftliche Buchgesellschaft, Darmstadt.

Teitler, H.C., 1985, Notarii and exceptores: An inquiry into role and significance of shorthand writers in the imperial and ecclesiastical bureaucracy of the Roman empire (from the early Principate to $c$. 450 A.D.), J.C. Gieben, Amsterdam.

Treggiari, S., 1969, Roman freedmen during the late Republic, Oxford University Press, Oxford.

Troll, D.A., 1990, 'The illiterate mode of written communication: The work of the medieval scribe', in R.L. Enos (ed.), Oral and written communication: Historical approaches, pp. 96-125, SAGE Publications, Newbury Park.

Turner, E.G., 1973, The papyrologist at work, Duke University, Durham.

Turner, E.G. \& Parsons, P.J., 1987, Greek manuscripts of the ancient world, 2nd edn., Clarendon, Oxford.

Van Galen, G.P., 1991, 'Handwriting: Issues for a psychomotor theory', Human Movement Science 10, 165-191.

Wainschenker, R., Doorn, J. \& Castro, M., 2002, 'Quantitative values for perceptual notion of speech speed', Medical Engineering $\mathcal{E}$ Physics 24, 479-483.

Webb, R., 2001, 'The progymnasmata as practice', in Y.L. Too (ed.), Education in Greek and Roman Antiquity, pp. 289-316, Brill, Leiden.

Woolf, G., 2000, 'Literacy', in A.K. Bowman, P. Garnsey \& D. Rathbone (eds.), The Cambridge Ancient History: Vol. 11, part 2. The High Empire, A.D. 70-192, 2nd edn., pp. 875-897, Cambridge University Press, Cambridge.

Youtie, H.C., 1971a, '盾 g r a mma t 0 : An aspect of Greek society in Egypt', Harvard Studies in Classical Philology 75, 160-176.

Youtie, H.C., 1971b, 'B r a de w gr a fvwn: Between literacy and illiteracy', Greek, Roman and Byzantine Studies 12, 239-261.

Youtie, H.C., 1975a, 'Because they do not know letters', Zeitschrift für Papyrologie und Epigraphik 19, 101-108.

Youtie, H.C., 1975b, 'UUpograf eu甘: The social impact of illiteracy in Greco-Roman Egypt', Zeitschrift für Papyrologie und Epigraphik 17, 201-221. 